\title{
PROBLEMATIKA PEMBELAJARAN PENDIDIKAN AGAMA ISLAM PADA PESERTA DIDIK
}

\author{
Tasurun Amma, Ari Setiyanto, Mahmud Fauzi
}

Sekolah Tinggi Ekonomi dan Bisnis Islam Darussalam OKI

tasurun@stebis-oki.ac.id, arisetiyanto27@gmail.com, mahmudfauzi@stebis-oki.ac.id

\begin{tabular}{ll}
\hline & Abstrak \\
\hline Article History & Learning is an interaction between \\
Received: 12-1-2021 & students and their environment, the \\
Revised: 14-1- 2021 & purpose is a changes behavior for the \\
Accepted: 26-1-2021 & better. Creating quality learning has \\
\hline Keywords: & many obstacles, mainly; the problem \\
Learning Problems, & of learning objectives, materials, \\
Islamic Education, & teachers, students, methods, media, \\
Student & infrastructure, and evaluation. \\
& Islamic Education Learning in \\
& Students there are three factors, the \\
& factors are Internal factors of \\
& students, institutional factors, and \\
& external factors. Solutions were made \\
& to solve the problems that occurred; \\
& provide guidance, added the values \\
& of the Islamic Religious Education \\
& subject, improving the ability of \\
& teachers, service, and activating \\
& community relations teacher and \\
& parent.
\end{tabular}

\section{Pendahuluan}

Undang-undang RI, No. 20 tahun 2003 tentang SISDIKNAS menyebutkan pendidikan adalah usaha sadar dan terencana untuk mewujudkan suasana belajar dan proses pembelajaran agar peserta didik secara aktif mengembangkan potensi dirinya untuk memiliki kekuatan spiritual keagamaan, pengendalian diri, kepribadian, kecerdasan, akhlak mulia, serta keterampilan yang diperlukan dirinya, masyarakat, bangsa dan negara. Tujuan pendidikan nasional kemudian dituangkan dalam pasal 3 yaitu Pendidikan nasional berfungsi mengembangkan kemampuan dan membentuk watak serta peradaban bangsa yang bermartabat dalam rangka mencerdaskan 
kehidupan bangsa, bertujuan untuk berkembangnya potensi peserta didik agar menjadi manusia yang beriman dan bertakwa kepada Tuhan Yang Maha Esa, berakhlak mulia, sehat, berilmu, cakap, kreatif, mandiri, dan menjadi warga negara yang demokratis serta bertanggung jawab.

Implementasinya bahwa berkaitan dengan peningkatan mutu nyatanya pendidikan tidak serta merta dapat berjalan dengan lancar, pemerintah sendiri telah melakukan banyak hal tentang bagaimana meningkatkan mutu pendidikan walaupun pada saat ini masih menjadi satu tantangan tersendiri (yeni rahmawati, 2017:04). Mutu atau kualitas pendidikan didalamnya mencangkup dua bagian utama yaitu; kualitas komponen dan kualitas pengelolaan (Umar Tirta R., 2010:41). Kualitas komponen maksudnya adalah bagaimana kualitas alat fisik dari suatu pedidikan, sedangkan kualitas pengelolaan yaitu bagaimana kualitas pengelolaan warga sekolah dalam menjalankan pendidikan. Kualitas pengelolaan didalamnya juga memuat bagaimana pembelajaran dilaksanakan.

Pembelajaran didalamnya memuat interaksi peserta didik terhadap lingkungan sekitarnya terutama adalah guru, sehingga terjdinya perubahan kedewasaan/tingkah laku yang lebih baik (E. Mulyasa, 2010:100) menciptakan kondisi pembelajaran yang baik dan berkualitas tentunya memiliki banyak hambatan-hambatan, hambatan tersebut dapat muncul dari berbagai komponen pembelajaran seperti; masalah tujuan pembelajaran, materi, guru, peserta didik, metode, media, sarana prasarana, dan evaluasi.

Seperti pendidikan pada umumnya, Pendidikan Agama Islam yang merupakan bagian dari satu keutuhan pendidikan di lingkup sekolah juga mengalami masalah-masalah serupa. Menyikapi munculnya masalah-masalah dalam proses pembelajaran Pendidikan Agama Islam (PAI) banyak kajian secara teoritis tentang permasalahan pembelajaran telah dikemukakan oleh peneliti. Disebutkan masalah/problematika dalam Pembelajaran Agama Islam yaitu : Problematika pada peserta didik yang sering muncul adalah minimnya kemampuan membaca tulisan arab, problem kesulitan dalam hafalan materi, kurangnya semangat/motivasi belajar dan problem dalam memahami materi yang disampaikan. Selain itu banyak lagi masalah yang dihadapi peserta didik dari aspek eksternalnya diantaranya guru sebagai pembimbing kurang kreatif dalamm mengembangkan pembelajaran atau menciptakan kegiatan- 
kegiatan keagamaan yang diluar jam kelas sehingga prstasi pesert didik hanya pada batas kognitif saja, problematika yang terjadi selanjutnya terjadi kurang tepatnya metode yang dipilih dalam pembelajaran sehingga kurang mengena terhadap belajar, terjadi juga kurangnya media-media belajar dalam sekolah tersebut, atau masalah lingkungan yang muncul dari rumah peserta didik masing-masing seperti masalah orang tua dalam mendidik, membimbing, dan masalah teman sebaya dan lingkungan masyarakatnya. Masyarakat adalah cerminan kedepan bagaimana kehidupan anak tersebut dikehidupan yang akan datang.

Pendapat lain tentang problematika pembelajaran PAI antara lain : Kurangnya tenaga pengajar, kurangnya fasilitas sekolah, alokasi waktu yang kurang tepat, jumlah peserta didik yang terlalu banyak (Muslimin, 2017:216). Abdul Majid juga menjelaskan tentang problematika pembelajaran PAI yaitu : Masalah peserta didik meliputi; tingkat kecerdasan peserta didik, alat penglihatan atau pendengaran kurang baik, kesehatan pesertadidik, masalah persepsi peserta didik, serta masalah kemampuan dalam gaya belajar, masalah lingkungan meliputi; kurikulum kurang sesuai, kualitas guru, metode tidak sesuai, alat dan media pembelajaran kurang memadai (Abdul Madjid, 2008:232).

Dari beberapa problematika di atas, problematika pembelajaran dapat muncul dari segala komponen pembelajaran. Terfokus kepada peserta didik sebagai objek dan subjek pembelajaran dalam rangka mengembangkan kemampuan dan potensinya sebagai bagian dai masyarakat yang berada pada jenjang pendididkan tertentu. Undangundang RI, No. 20 tahun 2003 tentang SISDIKNAS, Pasal 1 menyatakan bahwa peserta didik adalah komponen yang terpenting diantara kelompok lainnya. Pada dasarnya peserta didik adalah unsur penentu dalam proses belajar mengajar. Tanpa adanya peserta didik, sesungguhnya tidak akan terjadi proses pengajaran. Sebab peserta didiklah yang membutuhkan pengajaran dan bukan pendidik, pendidik hanya berusaha memenuhi kebutuhan yang ada pada peserta didik. Tanpa adanya peserta didik, pendidik tak akan mungkin mengajar.

Problematika yang dihadapi oleh peserta didik dalam pembelajaran PAI biasanya meliputi minimnya kemampuan membaca tulisan arab, problem kesulitan dalam hafalan materi, kurangnya semangat/motivasi belajar dan problem dalam memahami materi yang 
disampaikan. Faktor yang melatarbelakangi hal tersebut dapat dilihat dalam beberapa faktor; Faktor intern yaitu faktor yang muncul dari dalam diri pribadi peserta didik diantaranya adalah perbedaan kemampuan kecerdasan, kurangnya minat, motivasi dan bakat peserta didik pada pelajaran Pendidikan Agama Islam (PAI) dan faktor ekstern, yaitu keberadaan lingkungan peserta didik meliputi guru, kehidupan sosial orang tua, masyarakat dan lingkungan sekolah sendiri.

\section{Metode Penelitian}

Pendekatan yang digunakan dalam penelitian ini adalah pendekatan kualitatif yaitu suatu prosedur penelitian yang menghasilkan data deskriptif berupa ucapan atau tulisan dan perilaku yang dapat diamati dari subyek itu sendiri. (Arif Furchan, 1992:21). Penelitian kualitatif adalah jenis penelitian yang temuan-temuannya tidak diperoleh melalui prosedur statistik atau bentuk hitungan lainnya (Iman Gunawan, 2009:5). Menurut Sukmadinata, penelitian kualitatif adalah penelitian yang digunakan untuk mendeskripsikan dan menganalisis fenomena, peristiwa, aktivitas sosial, sikap, kepercayaan, persepsi dan orang secara individual maupun kelompok (Nana Syaodih Sukmadinata, 2009:53-60).

Jenis penelitian ini bersifat deskriptif yaitu penelitian yang menggambarkan data informasi yang berdasarkan dengan kenyataan (fakta) yang diperoleh di lapangan (Suharsimi Arikunto, 1993:309). Penelitian deskriptif sendiri merupakan penelitian yang paling dasar. Ditunjukkan untuk mendeskripsikan atau menggambarkan fenomena yang ada, baik fenomena yang bersifat ilmiah ataupun rekayasa manusia. Penelitian ini mengkaji bentuk, aktivitas, karakteristik, perubahan, hubungan, kesamaan dan perbedaannya dengan fenomena lain. Deskriptif kualitatif dalam penelitian ini digunakan untuk mengembangkan teori yang dibangun melalui data yang diperoleh di lapangan dengan menggunakan metode wawancara, dokumentasi, dan observasi.

Prosedur pengumpulan data dapat juga diartikan sebagai suatu usaha untuk mengumpulkan data. Teknik yang digunakan peneliti dalam penelitian ini adalah obsevasi, wawancara, dan dokumentasi. Sedangkan teknik analisis data melalui reduksi data, penyajian data, dan penarikan kesimpulan. 


\section{Pembahasan}

Peserta didik merupakan bagian terpenting sebagai objek pendewasaan. Oemar Hamalik berpendapat mengenai komponen pembelajaran dia mengatakan meliputi: tujuan, peserta didik, guru, planing belajar, media belajar, strategi belajar, dan evaluasi atau penilaian (Oemar Hamalik, 2010:23). Peserta didik merupakan bagian dari anggota masyarakat yang memiliki potensi fisik dan psikis yang membutuhkan usaha dan bantuan, arahan dan bimbingan orang lainyang lebih dewasa (guru dan lain-lain), untuk mengembangkan dirinya melalui proses pendidikan pada jenjang dan jenis pendidikan tertentu.

Perkembangan kurikulum saat ini, kurikulum yang digunakan pada proses pembelajaran sesuai dengan kurikulum terkini yakni Kurikulum 2013. Beberapa pengembangan metode, gaya belajar, materi, dan evaluasi belajar telah disesuaikan dengan kurikulum yang berlaku sehingga pelaksanaan pembelajaran secara umum berjalan dengan lancar.

Terkait problematika pembelajaran Pendidikan Agama Islam (PAI) pada peserta didik, masih ditemukan beberapa problem di dalamnya dan variatif. Sebagaimana pendapat Tohirin bahwa peserta didik di sekolah dan madrasah sebagai manusia (individu) dapat dipastikan memiliki masalah, akan tetapi kompleksitas masalahmasalah yang dihadapi oleh individu yang satu dengan yang lainnya tentulah berbeda-beda (Tohirin, 2007,111). Problematika pembelajaran PAI pada peserta didik dominan terhadap tiga aspek masalah yaitu; minat belajar, motivasi belajar, dan kesulitan belajar.

Minat belajar menurut Bloom bahwa "yang dimaksud Minat yaitu sesuatu yang menjadi penyebab seseorang menyukai terhadap sesuatu, didalamnya juga termasuk menyukai pelajaran tertentu" (Siswanto, 2013: 56). Pengertian lain menyebutkan minat adalah kecenderungan seseorang terhadap obyek atau sesuatu kegiatan yang digemari yang disertai dengan perasaan senang, adanya perhatian, dan keaktifan berbuat (Rusmiati, 2017:6).

Minat seyogyanya dimiliki oleh peserta didik dalam melaksanakan belajar karna minat terhadap sesuatu yang dipelajari dapat mempengaruhi sikap dalam belajar selanjutnya serta mempengaruhi penerimaan minat-minat baru. Slameto menuturkan : Minat terhadap sesuatu merupakan hasil belajar dan menyokong kegiatan belajar selanjutnya (Slameto, 2010:188). Minat dalam proses 
belajar mengajar merupakan salah satu faktor yang besar pengaruhnya terhadap ketercapaian tujuan belajar. Peserta didik yang minat belajarnya tinggi akan menumbuhkan sikap optimis dan senang dalam mengikuti menjalankan aktivitas terhadap hal-hal yang dipelajari kemudian peserta didik akan memperoleh keberhasilan dalam belajar.

Indikator-Indikator yang menunjukkan rendahnya minat belajar pada peserta didik ditunjukkan dalam beberpa hal, yaitu ; peserta didik tidak sampai selesai mengikuti KBM atau bolos belajar, peserta didik tidak masuk kelas tanpa keterangan, peserta didik ini tidak mengerjakan tugas baik itu PR atau tugas di kelas, tidur ketika pelajaran, asik terhadap kegiatan mereka masing-masing ketika pelajaran berlangsung, dan belum ada rasa butuh dan penting terhadap pelajaran PAI. hal ini menunjukkan kurangnya kemauan peserta didik dalam melaksanakan proses belajar PAI dan tidak adanya perhatian, ketertarikan, dan keterlibatan mereka terhadap mata pelajaran PAI. Sehingga bagi seorang guru maupun stake holder sekolah harus bekerja keras dalam menemukan solusi berkaitan dengan minat tersebut.

Motivasi atau dorongan adalah suatu pernyataan yang kompleks di dalam suatu organism yang mengarahkan tingkah laku terhadap suatu tujuan (goal) atau perangsang (incentive). Tujuan adalah yang menentukan atau membatasi tingkah laku organism itu. Jika ditekankan fakta atau objeknya yang menarik organism itu, maka dipergunakan istilah perangsang" (Purwanto, 2010:61).

Berdasarkan tersebut dapat disimpulkan pengertian motivasi yaitu keseluruhan daya penggerak baik dari dalam diri maupun dari luar dengan menciptakan serangkaian usaha untuk menyediakan kondisi-kondisi tertentu yang menjamin kelangsungan serta memberikan pandangan kedepan dengan dampak mengaruskan melaksanakan aktivitas yang diinginkan. Sebagaimana fungsi motivasi dalam belajar yang dikemukakan Oemar Hamalik bahwa semnagat/motivasi mendasari prilaku dalam belajar serta memberikan dampak pada hasil belajar peserta didik.

Rendahnya motivasi belajar memiliki dampak yang sangat jelas dimana dalam pembelajaran peserta didik akan bersikap biasa saja bahkan cenderung yang penting ikut di dalam kelas, tidak ada aksi konkrit yang dapat dilakukan oleh peserta didik tersebut terkait pembelajaran PAI di kelas. Beberapa indikator rendahnya motivasi 
belajar yang ditemukan yaitu; peserta didik yang suka membuat keributan di dalam kelas, mencontek, malas-malasan ketika pembelajaran PAI, malas mengikuti kegiatan keagamaan, sering terlambat masuk kelas ketika pelajaran PAI berlangsung, kurang aktif dalam mengeluarkan pendapat dan jarang bertanya, dan menunjukan akhlaknya kurang mencerminkan prilaku pembelajaran PAI baik di ruang kelas atau di lingkungan sekitar peserta didik.

Belajar merupakan kegiatan inti dari pendidikan itu sendiri dapat diartikan sebagai bantuan pengembangan individu melalui kegiatan belajar. Secara psikologis belajar merupakan sebuah proses mengubah atau berubahnya tingkah laku kepada pendewasaan dengan kematangan kognitif, afektif, dan psikomotorik dengan adanya interaksi individu dengan lingkungan sekitar untuk memperoleh respons yang diperlukan dalam interaksi dengan lingkungan sekitarnya. Menurut Rusmiati, belajar adalah proses terjadinya perubahan prilaku peserta didik pada akhir pembelajaran. Perubahan tersebut dapat diketahui melalui penilaian atau evaluasi terkait kognitif, afektif dan psikomotoriknya, namun yang lebih penting adalah perubahan prilaku peserta didik itu sendiri. Perubahan prilaku tersebut menunjukkan kematangan pemahaman terhadap suatu materi yang diterima oleh peserta didik dalam belajar.

Kegitatan belajar apabila tidak dirancang dengan baik maka dapat menimbulkan berbagai masalah baik bagi pelajar itu sendiri maupun bagi pengajar. Misal guru harus mampu menciptakan kondisi yang tertib dan kondusif dalam belajar agar tujuan belajar berhasil dicapai, memilih metode belajar dan alat-alat sesuai dengan jenis dan situasi belajar, membuat rencana belajar bagi peserta didik, menyesuaikan proses belajar dengan keunikan peserta didik, penilaian hasil belajar, diagnosis kesulitan belajar, dan sebagainya.

Bagi peserta didik, banyak masalah yang sangat mungkin menjadi halangan dalam belajarnya. Beberapa contoh masalah belajar tersebut seperti kesulitan membagi waktu, memahami pelajaran, meggunakan alat dan media belajar, kemampuan atau kecendrungan dalam memilih mata pelajaran, kemampuan belajar bersama, dan minimnya rasa percaya terhadap diri sendiri atau ide yang dia punya.

Secara umum, terdapat tiga faktor yang dapat mempengaruhi poses pembelajaran sebagai berikut; faktor Internal, institusional, dan ekternal. Faktor internal disini menyangkut masalah yang timbul pada diri pribadi anak itu sendiri. keberadaan peserta didik merupakan 
pelaku belajar dan sebagai objek pendewasaan. Artinya peserta didik adalah komponen yang tidak bisa ditinggalkan oleh pembelajaran itu sendiri.

Dalam pendidikan Islam, peserta didik adalah insan yang memiiki potensi yang baik yang harus dibimbing juga diarahkan kepada hal-hal yang baik. Selanjutnya, fungsi pendidikan adalah menyempurnakan iman, membentuk akhlakul karimah, cerdas, pengembangan mental, dan pengembangan bakat. Sehingga pada akhirnya peserta didik dapat menjalani kehidupannya sesuai dengan tuntunan Islam, hubungan hablu minallah, hablu minannas, dan hubungannya dengan alam semesta.

Abdul Aziz menyebutkan ada dua masalah penting dalam prblematika pembelajaran yaitu menyangkut perbedaan kejiwaan peserta didik dan perbedaan kemempuan berfikir atau iintelegensi (Abdul Aziz, 2001:37). Problematika merupakan sesuatu yang menghambat tercapainya tujuan-tujuan pembelajaran.

Faktor internal selanjutnya dalam belajar kadang disebabkan oleh tidak mencukupinya kegiatan belajar mengajar, buruknya pengajaran, guru yang tidak memadai, materi pelajaran yang sulit sehingga tidak dapat diikuti anak, atau tidak ada kesesuaian antara pelajaran-pelajaran yang ditetapkan dan bakat anak. Pendidik/guru yang kurang memadai merupakan salahsatu masalah dalam belajar peserta didik, hal ini mungin terjadi ketika guru belum atau tidak memiliki kompetensi standart guru atau masalah-malsah yang timbul oleh keondisi jasmani atau rohani guru itu sendiri pada saat prosses pembelajaran.

Sedangkan faktor institusional pertama adalah kurikulum sebagai subjek matter, plan activities, dan experien mengharuskan keberadaanya disiapkan direncanakan dengan baik. Didalamnya menyangkut keseluruhan perangkat pembelajaran meliputi tujuan, pendekatan dan metode, hingga evaluasi pembelajran itu sendiri. Menurut abdul majid Setidaknya ada empat kelompok dalam pengertian kurikulum yakni tujuan, isi, pola belajar mengajar, dan evaluasi (Abdul Majid, 2012:42).

Kurikulum sendiri memiliki pengertian yang beragam yaitu diantaranya adalah subject matter (content), program of plane activities, experiences, cultural production, dan agenda for sosial recontruction. Artinya kurikulum merupakan serangkaian kegiatan perencanaan dan pengembangan dalam proses pembelajaran. 
Selain kurikulum, manajemen dalam pendidikan Islam merupakan serangkaian pengaturan yang ada dalam pendidikan itu sendiri menyangkut seluruh komponen pendidikan untuk mencapai tujuan pendidikan. Faktor ini menyangkut pengelolaan dalam satuan pendidikan, didalamnya berisi bagaimana pmengatur sumber daya manusia (SDM), sarana prasarana, aturan yang berlaku, dan menyangkut Visi, Misi serta tujuan yang akan dicapai pengelola sekolah/lembaga pendidikan. Karena pendidikan yang berkualitas dapat dilihat darri pengelolaan dan pembelajaran yang berkualitas pula. Juga yang termasuk faktor institusional adalah sarana prasarana. Sarana prasarana menjadi begitu penting dalam proses belajar hari ini, karna kemajuan zaman dan teknologi tentunya mengharuskan proses belajar belajar khususnya sarana prasarana berkembang dengan baik. Selain itu cara pandang masyarakat terkini memiliki kesan bahwa sekolahan yang bagus dan lengkap secara materi sarana prasarana akan memiliki lebih banyak peserta didiknya dibandingkan dengan sekolah yang kondisinya minim. Sarana pendidikan yang dimaksud merupakan serangkaian alat atau bahan yang digunakan dalam belajar sebagai pendorong terwujudnya kegiatan belajar yang nyaman dan kondusip, seperti adanya meja dan kursi yang layak, papan tulis yang memadai, ketersediaan alat tulis, dan alat kebersihan. Sarana yang kurang memadai akan menjadikan pembelajaran kurang kondusip misalnya tidak adanya papan tulis maka guru dalam menjelaskan mungkin saja terhambat.

Faktor eksternal yang terpenting adalah lingkungan. Lingkungan keluarga dan masyarakat memiiki pengaruh penting dalam belajar peserta didik, pengaruh tersebut terus mengiringi broses belajar mereka tanpa bisa dibatasi sepenuhnya. Disini peserta didik harus mampu secara pribadi menyaring pengaruh itu sendiri. Problem lingkungan dapat timbul dari kehidupan di rumah dan lingkungan masyarakat. Akan ada perbedaan prilaku peserta didiksesuai dengan lingkungannya masing-masig, anak yang diknalkan dengan kawajiban dan hak dalam beragama, berumah tangga, bermasyarakat akan bebeda dengan yang tidak dikenalkan sama sekali. Lingkungan jyga bisa membentuk karakter anak diaman dia sering berinteraksi. Lingkungan yang agamis akan menumbuhkan prilaku anak yang agamis dan sebaliknya walaupun secara presentasi tidak menyeluruh namun hampir dapat dipastikan prilaku peserta didik mencontoh priaku yang ada di lingkungannya. Di sekolah, 
interaksi guru dan peserta ddik di luar kelas juga bisa mempengaruhi, guru yang menggunakan bahasa yang baik, sopan dan memiliki akhlak yang baik akan bisa menjadi contoh bagi peserta didik.

Terkait dengan hasil penelitian, Faktor yang mempengaruhi munculnya problematika pembelajaran Pendidikn Agama Islam (PAI) pada peserta didik diantaranya adalah :

\section{Faktor rendahnya minat belajar}

Keadaan fisik. seorang peserta didik pada dasarnya memiliki keterbatasan dalam melakukan aktivitas baik dalam berfikir atau kegiatan fisik lainnya. Peserta didik yang merasa capek atau bosan dalam mengikuti pelajaran akan cenderung merasa penting untuk memulihkan kondisi diri dari pada belajar, maka kemudian diantara akibat dari kondisi ini diantaranya peserta didik bolos sekolah atau tidur ketika pelajaran berlalngsung. Selain itu, kesiapan belajar peserta didik juga menjadi faktor penting dimana peserta didik harus siap secara fisik dan fikiran.

Orientasi atau kebutuhan, peserta didik harus terus didorong dalam meningkatkan minat dalam belajar agar dalam proses belajar memiliki arah berfikir yang positif terhadap satu mata pelajaran. Peserta didik yang menganggap bahwa satu mata pelajaran tidak penting atau tidak ia butuhkan maka secara otomatis minat terhadap mata pelajaran tersebut akan terus berkurang. Faktor-faktor pendorong timbulnya motivasi dan kesadaran siswa akan kebutuhan terhadap mata pelajaran diantaranya; hasil akhir atau laporan penilaian yang tinggi sehingga peserta didik mendapatkan peringkat, suatu dorongan batin untuk memuaskan rasa ingin tahu dalam satu atau lain bidang studi, keinginan memahami atau ketertarikan terhadap pelajaran yang ia anggap cocok dengan cita-citanya, pujian dari masyarakat sekolah atau rumah, dan dianggap dapat menjadi jalan keluar untuk masa depannya kelak.

Guru, keberadaan guru dalam mengajar menjadi poin utama dalam rangka membimbing, mengarahkan peserta didik menuju tujuan pembelajaran. Sehingga arahan, teguran, dan sikap yang baik bagi guru sangat dibutuhkan, guru dalam mengajarpun tidak boleh acuh terhadap pelanggarran-pelanggaran yang dilakukan peserta didik karena akibatnya peserta didik akan merasa leluasa melakukan pelanggaran yang kemudian akan menghabat proses belajar mengajar mereka. Selanjutnya metode yang dipakai dalam mengajar guru harus 
variatif disesuaikan dengan kondisi sekolah peserta didik dan materi yang diajarkan.

Menejemen lembaga sekolah, yang dimaksudkan disini adalah bagaimana pihak sekolah memberikan aturan-aturan kepada peserta didik ketika di sekolah dan bagaimana pula dalam menjalankan aturan yang ada tersebut secara terus menerus. Selain itu terkait hubungan sekolah dengan lingkungan peserta didik seperti orang tua atau masyarakat sekitar, hubungan yang baik terhadap lingkungan di luar sekolah.

Teman, keberadaan teman sekolah atau di rumah memberikan dampak besar bagi seorang peserta didik. Dimana sering terjadi peserta didik bolos, alpa, berprilaku buruk hanya harna ajakan seorang teman atau kebiasaan yang ia dan teman-teman lakukan di rumah.

Keluarga, peran penting keluarga dalam menjaga minat belajar peserta didik juga angat dibutuhkan. Perhatian, nasihat, contoh yang baik merupakan hal yang seharusnya terus diberikan oleh keluarga.

\section{Faktor minimnya motivasi belajar}

Kemampuan peserta didik, yang dimaksud adalah tingkat intelegensi dan gaya belajar peserta didik. Beberapa masalah yang timbul akibat perbedan kemampuan tersebut seperti malas mengerjakan tugas membaca atau menulis karna pada dasarnya peserta didik memiliki gaya belajar yang berbeda sedang metode yang digunakan belum mampu menampung gaya belajar secara mayoritas atau keadaan peserta didik yang malas mengerjakan tugas karna bagi mereka tugas tersebut terlalu berat. Artinya tindakan belajar dapat berhenti apabila sekolah atau guru tidak mampu mengenal kemampuan peserta didik tersebut. Padahal belajar akan akan dipermudah serta perkembangan kepribadian seimbang akan meningkat apaila pihak sekolah mengenal berbagai intelegensi dan berbagai gaya belajar (Oemar Hamalik, 2014:122).

Kondisi peserta didik, kondisi ini berkaitan dengan perasaan jasmani atau rohani peserta didik yang tentunya setiap individu dapat berbeda. Pearasaan malu atau sudah merasa bisa, sedang marah, atau kondisi fisik yang lelah dapat memberikan efek kurang baik dalam belajar sehingga terjadi beberapa priaku seperti malass bertanya, tidur, ngobrol dan lain-lain. Secara umum kondisi peserta didik dapat dipengaruhi oleh beberapa faktor yaitu : faktor 
hereditas/genitas, faktor lingkungan, dan faktor takdir (Reni Akbar, 2004:22-23).

Kondisi lingkungan peserta didik, lingkungan peserta didik disini yaitu kondisi lingkungan fisik sekitar seperti sarana prasarana sekolah, kondisi masyarakat sekitar, dan kondisi lingkungan keluarga. Keluarga kini cenderung mengalami disorientasi fungsi (Abdul Majid, 2014:270). Fungsi keluarga yang semula menjadi menjadi tempat pendidikan pertama bagi anak bergeser ke tempat lain yaitu sekolah atau masyarakat. Sehingga muncul dimana orang tua kurang perhatian, tidak memberikan pentingnya belajar, dan terkadang dalam mempersiapkan diri kesekolah sang anak sudah tidak lagi dianggap penting untuk tingkatan sekolah menengan keatas.

Pendidik/guru, guru merupakan penggerak kegiatan belajar bagi peserta didik. Guru yang profesional tentunya berkewajiban memenej proses belajar mengajar dengan baik dari segi perencaan yang berupa alat mengajar atau perangkatnya, aktualisasi, control, dan evaluasinya. Selain itu sebagai guru yang memiliki kompetensi kepribadian yang baik seorang guru diharapkan menjadi pribadi yang jujur, mantap, stabil, dewasa, arif, dan berwibawa. Jadi, guru dalam mengajar tidak boleh acuh terhadap kegiatan-kegiatan peserta didik selama proses belajar.

\section{Masalah belajar}

Kondisi lingkungan belajar, maksudnya yaitu keadaan lingkungan tempat belajar peserta didik di luar sekolah formal, menjadi hambatan apabila keadaan lingkungan tidak mendukung terhadap kegiatan belajar peserta didik. Menciptakan kondisi lingkungan peserta didik yang baik dan mampu mendorong terhadap kemampuan dan semangat belajar siswa sangatlah penting, beberapa bentuk menciptakan lingkungan ini adalah dengan upaya merealisasikan peraturan sekolah dengan baik, mengadakan kegiatan rutin keagamaan yang memungkinkan dilaksanakan pada jama sekolah, perhatian terhadap perkembanngan pesera didik, dan mendorong bakat dan potensi yang dimilki peserta didik dengan kegiatan di dalam maupun di luar sekolah. Hubungan sosial peserta didik, hubungan disini dimaksudkan bagaimana interaksi peserta didik dengan teman, guru, orang tua, dan masyarakat. Selanjutnya interaksi yang dilakukan oleh peserta didik sering kali menjadi 
masalah prilaku dalam belajar mangajar, peserta didik yang biasa berprilaku tidak mengikuti aturan di rumah atau lingkungannya maka di sekolahpun biasanya akan bersikap sama.

Adapun beberapa solusi mengatasi problem pembelajaran PAI pada peserta didik yang direalisasikan di sekolah yaitu Solusi yang direncanakan dan upayakan untuk menuntaskan atau meminimalisir problematika pembelajaran PAI pada peserta didik secara bertahap telah terlaksana denan baik. Beberapa upaya yang dilakukakn yaitu : melakukan bimbingan dan arahan agar selalu menjaga semangat dalam belajar kepada peserta didik oleh kepala sekolah, waka kepeserta didikan, dan guru. Selain semangat belajar guru juga enambahkan tentang pentingnya nilai-nillai mata pelajaran Pendidikan Agama Islam yang diajarkannya kepada peserta didik agar tidak timbul rasa tidak penting atau rasa tidak butuh bagi peserta didik. Upaya tersebut dilakukan dalam berbagai pertemuan baik di kelas, kegiatan upacara, dan kegiatan-kegiatan lain yang memungkinkan diberikan arahan tersebut kepada peserta didik. Pengembangkan potensi peserta didik diperlukan pengetahuan bagi pendidik tentang ciri khas peserta didik yaitu; individu yang memiliki potensi fisik dan psikis yang khas, indiidu yang sedang berkembang, individu yang membutuhkan bimbingan dan perlakuan manusiawi, dan individu yang memiliki kemampuan untuk mandiri (Umar Tirta Rahardja, 2010:52).

Meningkatkan motivasi atau semangat belajar peserta didik menurut Robert yaitu optimalisasi penerapan prinsip belajar, optimalisasi unsur dinamis belajar dan pembelajaran, optimalisasi pemanfaatan pengalaman dan kemampuan peserta didik juga pengembangan cita-cita dan aspirasi belajar. Pelaksanaan kegiatan belajar mengajar di sekolah tentunya memiliki waktu yang sangat terbatas, dengan hal tersebut tentunya guru harus memberikan alternatif optimalisasi pembelajaran melalui pemberian kesempatan pada peserta didik untuk mengungkap hambatan belajar yang dialaminya, memelihara minat, kemauan, dan semangat belajarnya sehingga terwujud tindak belajar, meminta kesempatan pada orang tua atau wali, agar member kesempatan kepada peserta didik untuk beraktualisasi diri dalam belajar, memanfaatkan unsur-unsur lingkungan yang mendorong belajar, menggunakan waktu secara tertib, penguat dan suasana gembira terpusat pada perilaku belajar, guru merangsang peserta didik dengan penguat memberi rasa 
percaya diri.

Upaya yang dilakukan pada pendidik dalam hal ini adalah guru juga dilakukan meliputi meningkatkan kemampuan guru Pendidikan Agama Islam melalui update skill terkhusus terkait dengan memenej proses pembelajaran, metode dan gaya belajar. Peningkatan kemampuan guru tersebut dilakukan dalam berbagai cara yaitu mengikuti workshop keguruan, pelatihan-pelatihan mengajar, dan pelatihan yang disediakan oleh pihak sekolah sendiri serta guru belajar secara mandiri menggunakan refrensi-refrensi terkini. Upaya lain yaitu menumbuhkan pribadi yang berwibawa, tegas, dan bersikap tak acuh terhadap peserta didik dalam kegiatan belajar mengajar, penampilan, dan keteladanan pribadi guru yang baik.

Sekolah sebagai tempat melaksanakan proses belajar mengajar melalui penglola sekolah berperan aktif dalam malakukan upayaupaya mengatasi problematika pembelajaran PAI pada peserta didik. Beberapa solusi yang dilakukan yaitu ; memberikan layanan terbaik. Meningkatnya layanan yang profesional segala bidang kehidupan merupakan ciri penting bagi kebutuhan manusia. Dalam hal melengkapi dan memperbaiki sarana prasarana yang dibutuhkan baik oleh guru ataupuun peserta didik, memciptakan iklim sekolah yang kondusif dan nyaman untuk belajar, memiliki programprogram pengembangan skill peserta didik khususnya dalam mata pelajaran PAI, dan mengaktifkan kegiatan keagamaan di sekolah. Upaya pengelola sekolah serta pendidik/guru dalam mengatasi masalah tersebut yaitu mengaktifkan dan memperbaiki hubungan masyarakat melalui rapat guru dan orang tua, home visit, kunjungan orang tua ke sekolah, pemanggilan orang tua, dan sharing perkembangan peserta didik melalui media tekhnologi

\section{Simpulan}

Problematika pembelajaran PAI pada peserta didik dominan terhadap tiga aspek masalah yaitu : pertama. Minat belajar beberapa indikatornya adalah Peserta didik tidak sampai selesai mengikuti KBM atau bolos belajar, Peserta didik tidak masuk kelas tanpa keterangan, Peserta didik ini tidak mengerjakan tugas baik itu PR atau tugas di kelas, Tidur ketika pelajaran, Asik terhadap kegiatan mereka masing-masing ketika pelajaran berlangsung, dan Belum ada rasa butuh dan penting terhadap pelajaran PAI. Kedua, Motivasi 
belajar dengan indikator yang masalah yaitu; Peserta didik ribut dikelas, sering mencontek, masih malas-malasan ketika belajar mata pelajaran PAI di kelas, Peserta didik malas mengikuti kegiatan keagamaan, Peserta didik sering terlambat masuk kelas ketika pelajaran PAI berlangsung, Kurang aktif dalam mengeluarkan pendapat dan jarang bertanya, dan Peserta didik menunjukan akhlaknya kurang mencerminkan prilaku pembelajaran PAI baik di ruang kelas atau di luar. Ketiga, Masalah belajar meliputi Masalah membagi waktu belajar dan sulit menghafal.

Faktor yang mempengaruhi proses pembelajaran Pendidikan Agama Islam (PAI) pada peserta didik yaitu; Faktor Internal (individu peserta didik), Faktor institusional (kurikulum, sarana prasarana, dan menejemen), dan Faktor Eksternal (individu di luar peserta didik dan lingkungan). Beberapa solusi yang dilakukan untuk memecahkan problem yang terjadi yaitu; melakukan bimbingan dan arahan agar selalu menjaga semangat dalam belajar kepada peserta didik oleh kepala sekolah, waka kepeserta didikan, dan guru. menambahkan tentang pentingnya nilai-nillai mata pelajaran Pendidikan Agama Islam (PAI), meningkatkan kompetensi guru mata pelajaran Pendidikan Agama Islam, memberikan layanan terbaik, dan mengaktifkan dan memperbaiki hubungan masyarakat melalui rapat guru dan orang tua, home visit, kunjungan orang tua ke sekolah, pemanggilan orang tua, dan sharing perkembangan peserta didik melalui media teknologi. 


\section{DAFTAR PUSTAKA}

Abdul Aziz As-Asykh, 2001. Kelambanan dalam Belajar dan Cara Penanganannya. Jakarta: Gema Insani.

Abdul Majid, 2012. Belajar dan Pembelajaran Pendidikan Agama Islam. Bandung: PT Remaja Rosdakarya.

Arif Furchan, 2012. Pengantar Metodologi Penelitian Kualitatif, Surabaya: Usaha Nasional.

Elgi Syafni Dkk. "Masalah Belajar Peserta Didik Dan Penanganannya", Konselor; Jurnal Ilmiah Konseling, Vol. 2 No. 2 Juni 2013.

Hamzah B Uno, 2011. Teori Motivasi dan Pengukuranya. Jakarta: Bumi Aksara.

Hayatus, Rosita, Herman, Rahmatina, Sastri, S. "Hubungan Status Gizi Dengan Prestasi Belajar Peserta Didik Sekolah Dasar Negri 01 Guguk Malintang Kota Padang Panjang”. Jurnal Kesehatan Andalas, 2014. 3 (3).

Kusdiana, A". Pembelajaran Apresiasi Sastra Cerita Terpadu Model Connected Untuk Meningkatkan Kemampuan Berbahasa Peserta Didik Sekolah Dasar". Jurnal Penelitian Pendidikan, 11 (1).

Lexy J. Moleong, 2012. Metodologi Penelitian Kualitatif. Bandung: PT Remaja Rosdakarya.

M. Indra Saputra, "Hakikat Pendidik Dan Peserta Didik Dalam Pendidikan Islam", Al-Tadzkiyyah; Jurnal Pendidikan Islam, Vol. 6 November 2015.

Marno, 2018. Modul Pengembangan Bahan Ajar Pai Pada Sekolah, (Hak Penerbitan: Direktorat Pendidikan Agama Islam Pada Sekolah (DITPAIS) Direktorat Jenderal Pendidikan Islam.

Muslimin, "Problematika Pembelajaran Pendidikan Agama Islam

Dan Upaya Solusi Guru Dalam Pembinaanya Di Sekolah",

Tarbawiyah: Jurnal Ilmiah Pendidikan, Vol. 01 N0. 02 Desember 2017.

Nana Syaodih Sukmadinata, 2009. Metode Penelitian Pendidikan. Bandung: Remaja Rosdakarya.

Oemar Hamalik, 2014. Psikologi Belajar Dan Mengajar. Bandung: Sinar Baru Algensindo.

Purwanto, M.N. 2010. Psikologi Pendidikan. Bandung: PT Remaja Rosdakarya. 
Rahmawati, F. "Pengaruh Pendekatan Pendidikan Realistik Matematika Dalam Meningkatkan Kemampuan Komunikasi Matematis Peserta Didik Sekolah Dasar". Prosiding Semirata 2013, 1 (1)

Raymond J Wlodkowskindan Judith H. Jaynes, Hasrat Untuk Belajar Terj. Nur Setiyo Budi Widarto. 2004. Yogyakarta: Pustaka Pelajar.

Reni Akbar \& Hawadi. 2004. Psikologi Perkembangan Anak: Mengenal Sifat, Bakat, dan Kemampuan Anak. Jakarta : PT Grasindo.

Rusmiati, "Pengaruh Minat Belajar Terhadap Prestasi Belajar", Dalam Utility: Jurnal Ilmiah Pendidikan Dan Ekonomi, Vol.1, No. 1 Februari 2017.

Suherman, A. Model Pembelajaran Pakem Dalam Pendidikan Jasmani di Sekolah Dasar. Jurnal Penelitian Pendidikan, 2010, Vol. 11, No. 1.

Sukardi. 2008. Metodologi Penelitian Pendidikan Kompetensi dan Prakteknya. Jakarta: PT Bumi Aksara.

Surya Muhammad. 2005. Psikologi Pendidikan. Bandung: FIP-Ikip Bandung.

Syaiful Bahri. 2010. Strategi Belajar Mengajar. Jakarta: Rineka Cipta.

Tohirin. 2007. Bimbingan Konseling di Sekolah dan Madrasah. Jakarta: PT Raja Grafindo Persada.

Umar Tirta Rahardja. 2010. Pengantar Pendidikan. Jakarta: PT Rineka Cipta. 